\title{
Metacercariae of Austrodiplostomum spp. (Digenea: Diplostomidae) infecting the eyes and brains of fish in Brazilian Amazon
}

\section{Metacercaria de Austrodiplostomum spp. (Digenea: Diplostomidae) infectando olhos e cérebros de peixes na Amazônia Brasileira}

\author{
Márcio Jonathan Soares Lima' (D), Renato Pastor Veiga' (D), \\ Luciclara Ferreira de Sousa' (D), Maxwell Barbosa de Santana' (D), \\ Marcos Sidney Brito Oliveira ${ }^{2}$ (D), Marcos Tavares-Dias ${ }^{2}$ (D), Lincoln Lima Corrêa ${ }^{1 *}$ (i)
}

\begin{abstract}
The aim of this paper was to report the occurrence of Austrodiplostomum spp. in the eyes and brain of Acaronia nassa, Caquetaia spectabilis, Satanoperca acuticeps, Curimatella sp. and Crenicichla marmorata in a lake of the Amazon River system in the state of Pará (Brazil). Of 49 fish examined, 10.2\% were parasitized by Austrodiplostomum spp. metacercariae, and A. nassa was the host with higher number of metacercariae. In five examined fish species, a total of 51 metacercariae were collected, with 45 found in the eyes and 6 in the cranial vault. In the eyes, the metacercariae were free and active in the vitreous humor, but no opacification was observed. In the brain, the metacercariae were also free and active, and located mainly below the encephalon, on the cranial floor, at the height of the ophthalmic lobes and near the optic nerve. In laboratory observations, however, the infected fish did not exhibit any behavioral disorders, and this may be related to the low level of parasitism. This was the first report of this digenean for C. spectabilis, S. acuticeps, Curimatella sp., C. marmorata and $A$. nassa.
\end{abstract}

KEYWORDS: Amazon; Digenea; parasites; freshwater fish.
RESUMO: O objetivo deste trabalho foi relatar a ocorrência de Austrodiplostomum spp. nos olhos e cérebros de Acaronia nassa, Caquetaia spectabilis, Satanoperca acuticeps, Curimatella sp. e Crenicichla marmorata em um lago do rio Amazonas no estado do Pará (Brasil). Dos 49 peixes examinados, 10,2\% foram parasitados por metacercárias de Austrodiplostomum spp., $A$. nassa sendo o hospedeiro com maior número de metacercárias. Em cinco espécies de peixes examinadas, foram coletadas 51 metacercárias, sendo 45 encontradas nos olhos e 6 na caixa craniana. Nos olhos, as metacercárias estavam livres e ativas no humor vítreo, mas nenhuma opacificação foi observada. No cérebro, as metacercárias também eram livres e ativas, localizadas principalmente abaixo do encéfalo, no assoalho do crânio, na altura dos lobos oftálmicos e próximo ao nervo óptico. Em observações laboratoriais, no entanto, o peixe infectado não apresentou distúrbios comportamentais, o que pode estar relacionado ao baixo nível de parasitismo. Este foi o primeiro relato de Austrodiplostomum spp. em C. spectabilis, S. acuticeps, Curimatella sp., C. marmorata e A. nassa.

PALAVRAS-CHAVE: Amazônia; Digenea; parasitas; peixes de água doce.

\footnotetext{
'Universidade Federal do Oeste do Pará - Santarém (PA), Brazil

${ }^{2}$ Embrapa Amapá - Macapá (AP), Brazil

*Corresponding author: lincorre@gmail.com

Received on: 08/13/2018. Accepted on: 08/07/2019
} 


\section{INTRODUCTION}

The Amazon River system is formed by various orders of rivers, lakes, and other geographic events. It contains around $20 \%$ of world's freshwater and a tremendous richness of fish, and its approximately 3,000 species (JUNK, 2013) make it one of the main resources for human food and the local economy. These fish are hosts for a variety of groups of Digenea from the Diplostomidae family, including Austrodiplostomum spp. LOCKE et al. (2010) have suggested that the identification of these metacercariae may not be based only on morphology, and the use of molecular markers is required. So, in this paper we considered the name Austrodiplostomum spp.

Austrodiplostomum spp. has been responsible for verminous cataracts, also known as diplostomosis, in freshwater fish. The metacercariae of these digeneans that infect the eyes of fish can be found in the retina, vitreous, aqueous, and/or crystalline humor, and also in the brains of hosts. The presence of these metacercariae at heightened levels of abundance can cause exophthalmos, displacement of the retina, opacity of the crystalline lens, blindness, and even the death of host fish (HECKMANN, 1992; BULLARD; OVESTREET, 2008; MONTEIRO et al., 2016; VITAL et al., 2016). The formation of cataracts in infected fish is more intense after the parasites complete their larval development and are ready to infect the definitive host, augmenting the susceptibility of intermediate host fish to predation (SANTOS et al., 2002; PINTO; MELO, 2013; CORRÊA et al., 2014). This is therefore an efficient transmission method for these digeneans (MOURITSEN; POULIN, 2003; VITAL et al., 2016).

Austrodiplostomum spp. occurs in fish in North and South America (BULLARD; OVESTREET, 2008). In Brazil, it has been registered infecting the eyeballs of Geophagus brasiliensis (NOVAES et al., 2006), Geophagus surinamensis (SANTOS et al., 2002), Cichla ocellaris (SANTOS et al., 2002), Cichla sp. (SANTOS et al., 2002), Cichla monoculus (MACHADO et al. 2005; VITAL et al. 2016), Satanoperca papaterra (MACHADO et al. 2005), Hoplias malabaricus (SANTOS et al., 2002; CORRÊA et al., 2014), Hypostomus regani (YAMADA et al., 2008; ZICA et al., 2009), Schizodon borellii, Auchenipterus osteomystax, Serrasalmus maculatus (YAMADA et al., 2008), and Plagioscion squamosissimus (KOHN et al. 1995; SANTOS et al., 2002; MACHADO et al., 2005; SANTOS et al., 2002; ALBUQUERQUE et al., 2017), all of which are fish from different ecosystems. Despite the wide distribution and the increasing number of cases of occurrence of these eye fluke infections in Brazilian fish, the possible impacts on wild fish species remain unknown or neglected. Furthermore, despite the large number of fish in the Brazilian Amazon, infection has been described in only nine species in the region (VITAL et al., 2016). The objective of the present study was therefore to report the occurrence of metacercariae of Austrodiplostomum spp. in the eyes and brain of five species of fish from a lake in the Amazon River system in the north of Brazil, and to evaluate the possible disorders in the behavior of infected hosts.

\section{MATERIALS AND METHODS}

In October 2016, specimens of Acaronia nassa Heckel, 1840 (Cichlidae); Caquetaia spectabilis Steindachner, 1875 (Cichlidae); Satanoperca acuticeps Heckel, 1840 (Cichlidae); Curimatella sp. Eigenmann \& Eigenmann, 1889 (Curimatidae) and Crenicichla marmorata Pellegrin, 1904 (Cichlidae) were collected in Lake Maicá in the state of Pará, Brazil (Fig. 1). This lake is located in the east of the municipal region of Santarém in the state of Pará, beginning in the Amazon River and extending as far as the Paraná do Ituqui River. It is connected to smaller lakes and contains various species of flora and fauna typical of the Amazon lowlands along its length.

Nets with differing mesh sizes were used for fish collection. These were placed at five points distributed along Lake Maicá (P1 02²8'25"S 05439'23,7”W; P2 02²8'23,7"S 054³9'23,7”W; P3 02'28'24,4”S 054'39'16,4”W; P4 02²8'24,9"S 054'39'10,8”W, and P5 $02^{\circ} 28^{\prime} 23,4^{\prime \prime}$ ' $054^{\circ} 39^{\prime} 09,0^{\prime \prime} \mathrm{W}$ ) and inspected every four hours. Following capture, all the fish were transported in water tanks to the Multi-laboratory for the Production of Aquatic Organisms Laboratório Múltiplo de Produção de Organismos Aquáticos (LAMPOA), where they were kept in aquariums with a capacity of $120 \mathrm{~L}$ and were treated for seven days with $\mathrm{NaCl}\left(100 \mathrm{~g} / \mathrm{m}^{3}\right)$, against possible cutaneous infection caused by capture and/or transport. Following identification, representative specimens of the parasites were deposited in the Zoological Collection of the Zoological Museum of UNICAMP, under voucher number ZUECPLA 16.

The fish were euthanized for parasitological analysis using the transection of the cervical cord method for parasitological analysis. The total length $(\mathrm{cm})$ and weight $(\mathrm{g})$ were measured, and the organs were examined to verify the occurrence of metacercariae of Austrodiplostomum spp. The metacercariae found were compressed between a slide and a cover slip, fixed in AFA ( $70 \%$ alcohol, formalin and acetic acid) and preserved in $70 \%$ alcohol. The metacercariae were subsequently stained with Carmine de Langeron, clarified with Methyl Salicylate, and mounted on permanent slides using Canada balsam (EIRAS et al., 2006). The taxonomic identification of the parasites was carried out in accordance with KOHN et al. (1995) and GIBSON et al. (2002). The morphometric analysis of the metacercariae was performed using an optical microscope (Zeiss Axioplan), the images were obtained with a digital camera (coupled Axiocam ERc 5s), and the measurements $(\mu \mathrm{m})$ were performed using the Zen program. The ecological terms used (prevalence, mean intensity and abundance) were in accordance with the recommendations of BUSH et al. (1997).

\section{Compliance with Ethical Standards}

Fish collection was authorized by IBAMA/ICMBio (no. 46202-3/2017). The collection and euthanasia procedures of the fish were approved by the Ethics Committee for Animal Research of the Universidade Federal do Oeste do Pará (West Pará Federal University) (no. 06001/2015 — CEUA/UFOPA). 


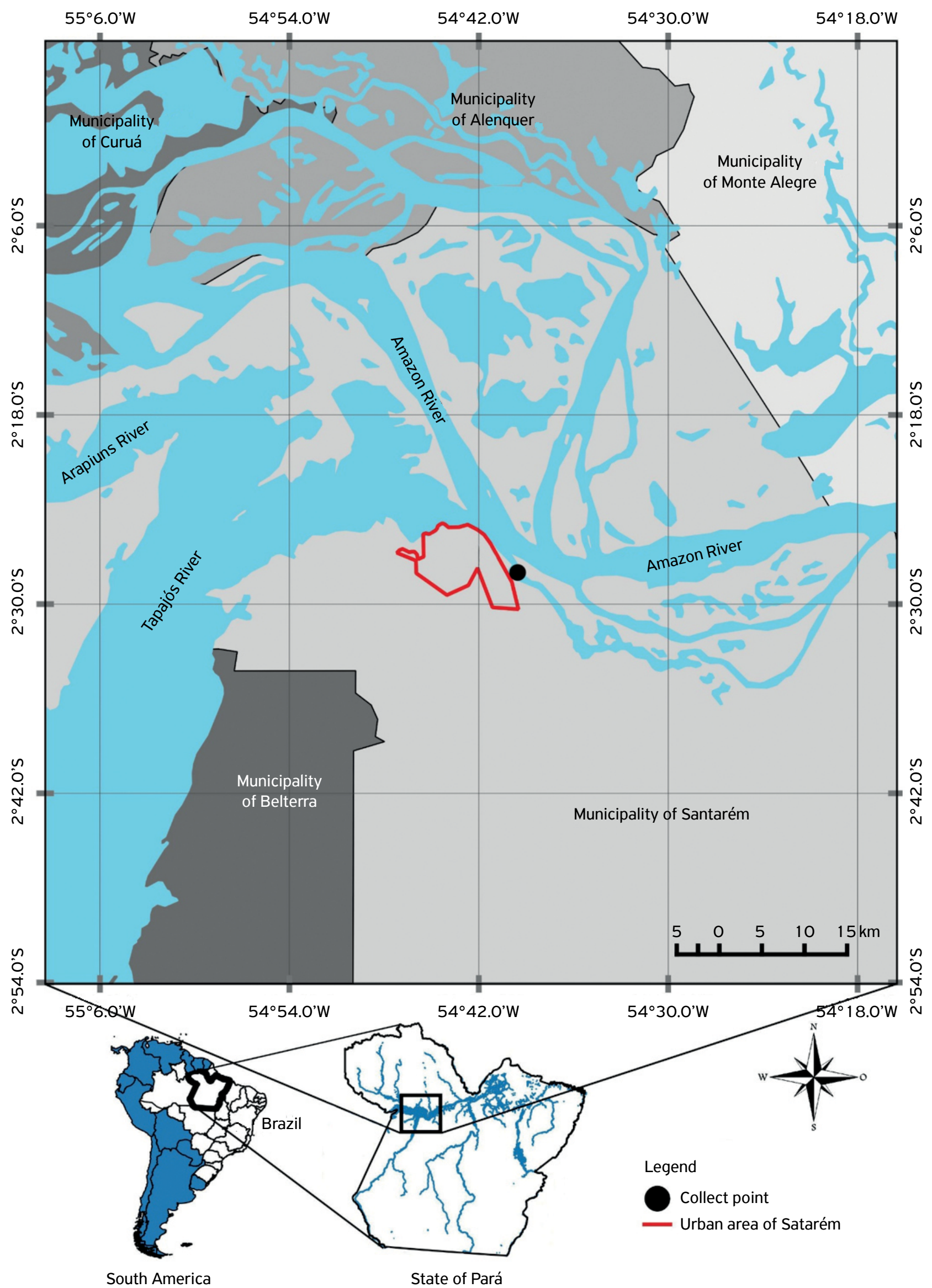

Figure 1. Localization and georeferencing of collection points of fish species in a lake in eastern Amazon (Brazil). 


\section{RESULTS}

Of a total of 49 fish specimens from five species necropsied (Table 1 and Fig. 2), 10.2\% were parasitized by metacercariae of Austrodiplostomum spp. A total of 51 metacercariae were recovered, being 45 from the eyes and 6 from the brain. In $A$. nassa were recovered 18 metacercariae and $S$. acuticeps 15 metacercariae (Table 2).

In the host eyes, the metacercariae were free and active in the vitreous humor, but no sign of opacification was observed.

Table 1. Biometric parameters of fish infected by Austrodiplostomum spp. collected in a lake in eastern Amazon (Brazil).

\begin{tabular}{lcccc} 
Hosts & N & Weight $(\mathbf{g})$ & Total length $(\mathbf{c m})$ & Standard length $(\mathrm{cm})$ \\
\hline Caquetaia espectabilis & 19 & $68.5 \pm 59.8$ & $16.0 \pm 3.4$ & $13.3 \pm 2.9$ \\
\hline Satanoperca acuticeps & 4 & $46.4 \pm 1.0$ & $14.0 \pm 1.0$ & $11.5 \pm 1.0$ \\
\hline Curimatella sp. & 19 & $6.5 \pm 1.0$ & $3.0 \pm 1.0$ & - \\
\hline Crenicicla marmorata & 1 & 181.2 & 27.5 & 24.5 \\
\hline Acaronia nassa & 6 & $77.0 \pm 1.0$ & $15.5 \pm 1.0$ & $12.0 \pm 1.0$ \\
\hline
\end{tabular}
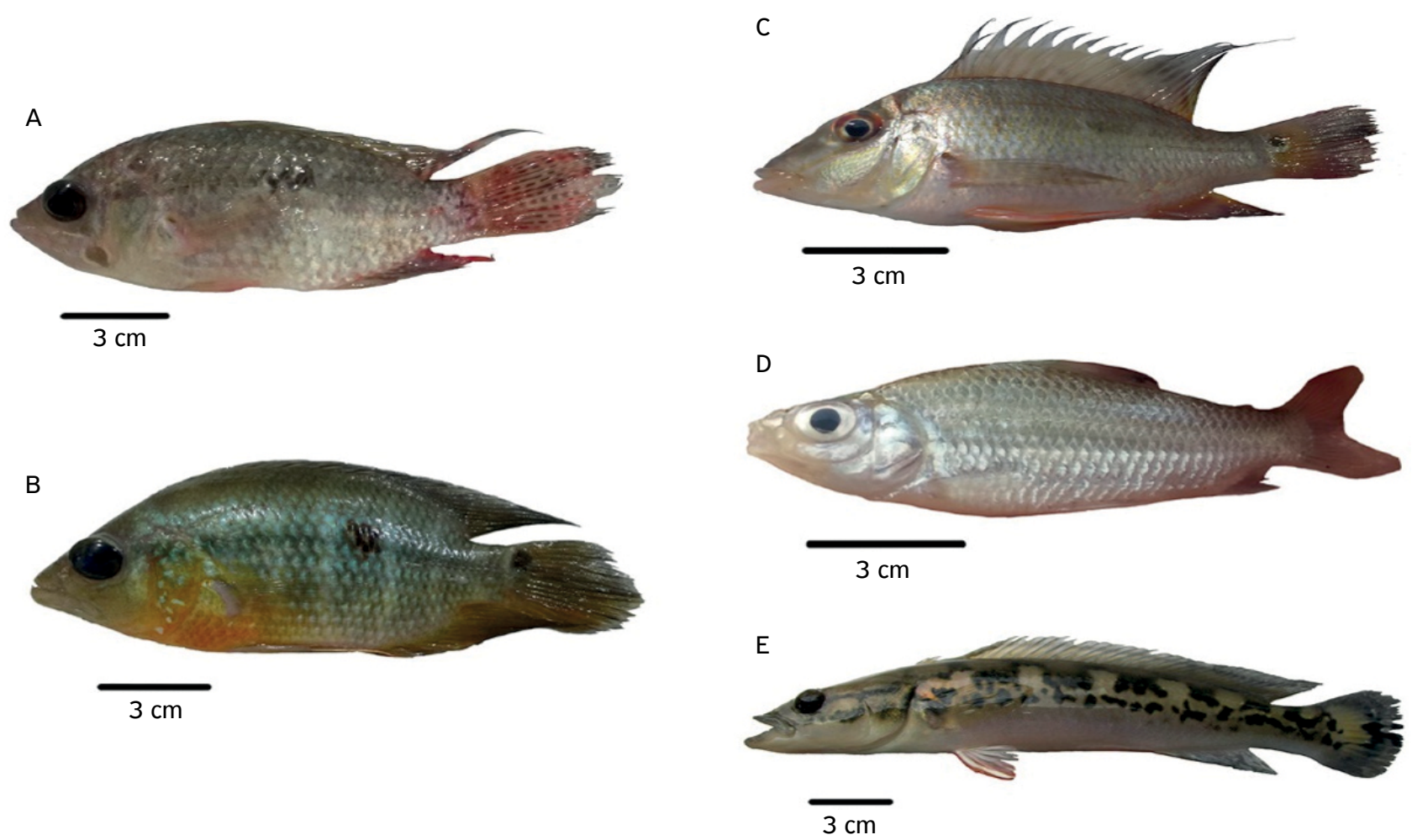

Figure 2. Species of host fishes infected by Austrodiplostomum spp. in a lake in eastern Amazon (Brazil). (A) Acaronia nassa; (B) Caquetaia spectabilis; (C) Satanoperca acuticeps; (D) Curimatella sp.; (E) Crenicichla marmorata.

Table 2. Levels of infection by Austrodiplostomum spp. in fish from a lake in eastern Amazon (Brazil).

\begin{tabular}{lcccccccc} 
& \multicolumn{3}{c}{ Levels of infection } & \multicolumn{5}{c}{ Infection sites } \\
\cline { 2 - 9 } Hosts & FE/PF & P (\%) & MI & MA & RE & LE & CV & TNP \\
Caquetaia espectabilis & $19 / 1$ & 5.3 & 1.0 & $0.05 \pm 0.2$ & 0 & 1 & 0 & 1 \\
\hline Satanoperca acuticeps & $4 / 1$ & 25.0 & 15.0 & $3.7 \pm 7.5$ & 8 & 5 & 2 & 15 \\
\hline Curimatella sp. & $19 / 1$ & 5.3 & 2.0 & $0.1 \pm 0.4$ & 2 & 0 & 0 & 2 \\
\hline Crenicichla marmorata & $1 / 1$ & 100 & 15.0 & $15.0 \pm 0$ & 5 & 7 & 3 & 15 \\
\hline Acaronia nassa & $6 / 1$ & 16.7 & 18.0 & $3.0 \pm 7.3$ & 7 & 10 & 1 & 18 \\
\hline
\end{tabular}

P: prevalence; MI: mean intensity; MA: mean abundance; RE: right eye; LE: left eye; CV: cranial vault; FE: fish examined; PF: parasitized fish; TNP: total number of parasites. 
In the cerebral vault, the metacercariae were also free and active, and located mainly below the brain, on the cranial floor, at the height of the ophthalmic lobes, near the optic nerve. It was observed that the ophthalmic lobes, especially the veins that irrigate this region, were dilated and highly visible in the parasitized fish, a characteristic not observed in non-parasitized fish and/or those parasitized only in the eyes. However, in laboratory observations, the fish showed no behavioral changes.

Austrodiplostomum spp. exhibited a foliaceous body, slightly concave on the ventral surface, small conical segments in the posterior region, an oral suction cup located at the anterior extremity, pseudo-suckers located laterally to the oral suction cup, and an oval pharynx (Fig. 3). The morphometric measurements of the metacercariae were compared with those described in the literature (Table 3).

\section{DISCUSSION}

Although metacercariae of Austrodiplostomum spp. have been found infecting the eyes, gills, swimming bladder, and musculature of several South American fish species due to their low parasitic specificity (ZICA et al., 2011) they infect the brains of hosts less frequently. In this study, we found lower intracranial abundance than in the eyes of infected fish. HECKMANN (1992) reported that infections of metacercariae of Diplostomum mordax in the cranial cavity of Orestias agasii, O. olivaceus, $O$. luteus and Basilichthys bonariensis induced compression of the neural tissue and migration of the metacercariae to the brain, leading to hemorrhage; cell necrosis; inflammation; fibrosis and the rupture of nerve fibers. However, such alterations were not observed in fish in the present study infected by Austrodiplostomum spp., due to the low levels of parasitism, a finding corroborated by SIEGMUND et al. (1997) in Basilichthys austrais infected by metacercariae of Diplostomum mordax and Tylodelphys destructor. CORREA et al. (2014) reported that $H$. malabaricus, with widespread infection by Austrodiplostomum spp. in the eyes and cranial cavity, presented alterations in swimming capacity such as imbalance and a lack of coordination. Host size, duration of transmission period, and host growth rate are important factors in brain disorders

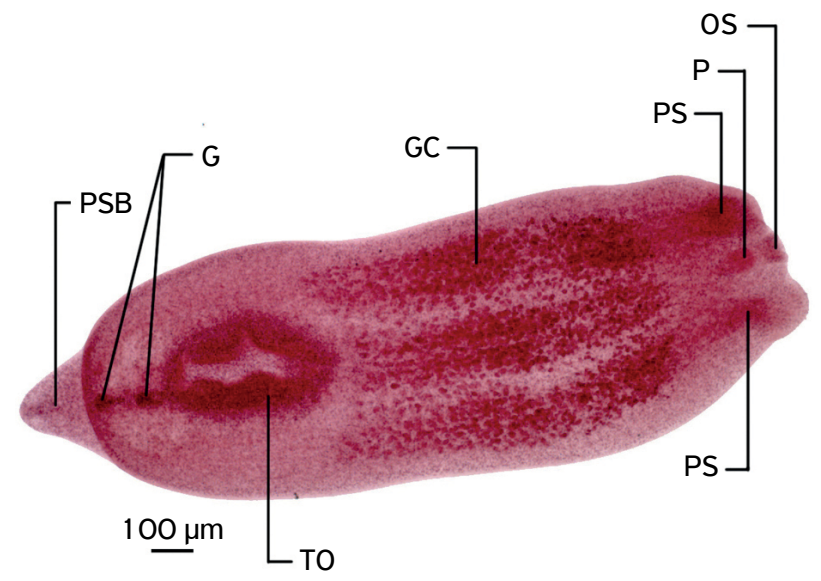

OS: oral suckers; P: pharynx; PS: pseudo-suckers; GC: gland cells; TO: tribocytic organ; G: gonads; PSB: posterior segment of the body.

Figure 3. Metacercaria of Austrodiplostomum spp. from eyes and brain of fish species from a lake in eastern Amazon (Brazil).

Table 3. Comparison of morphometric $(\mu \mathrm{m})$ values of Austrodiplostomum spp. metacercariae in fish from a lake in eastern Amazon (Brazil) with studies carried out in Brazil.

\begin{tabular}{|c|c|c|c|}
\hline Parasite measures & $\begin{array}{l}\text { Lake Maicá, Pará state } \\
\text { (Present study - } n=5 \text { ) }\end{array}$ & $\begin{array}{l}\text { Paraná River, Paraná state } \\
\text { (YAMADA et al. } 2008-n=6 \text { ) }\end{array}$ & $\begin{array}{l}\text { Lake Catalão, Amazonas } \\
\text { state (ALBUQUERQUE et al. } \\
2017-n=15 \text { ) }\end{array}$ \\
\hline Total length & $1800(1584-1947)$ & $1037(680-1190)$ & $1783.5(148.2-2024.4)$ \\
\hline Overall width & $642(537-709)$ & $568(310-1010)$ & $662.2(589.1-782.4)$ \\
\hline Length of oral suction cup & $59(45-83)$ & $46(19.2-60)$ & $60.5(44.8-72.4)$ \\
\hline Width of oral suction cup & $68(54-77)$ & $48,8(28.8-60)$ & $70.1(47.6-81.7)$ \\
\hline Length of pharynx & $61(53-73)$ & $60(36-96)$ & $62.9(46.9-79.4)$ \\
\hline Width of pharynx & $56(50-64)$ & $40(14.4-55.2)$ & $57(41.3-69)$ \\
\hline Length of right pseudo-suckers & $99.4(71.6-124.8)$ & - & $103.8(74.1-127.4)$ \\
\hline Width of right pseudo-suckers & $95.4(69.6-190.2)$ & - & $80.6(59.5-95.1)$ \\
\hline Length of left pseudo-suckers & $93.8(71.3-125.3)$ & - & $99.5(83.6-121.7)$ \\
\hline Width of left pseudo-suckers & $83.4(63.6-116.4)$ & - & $83.1(63.7-105.6)$ \\
\hline Length of tribocytic organ & $428(422-434)$ & $236(91.2-324)$ & $344.9(230.3-425.2)$ \\
\hline Width of tribocytic organ & $258(220-319)$ & $152(81.6-228)$ & $181.1(122.2-238.2)$ \\
\hline Acetabulum length & $17.7(4.8-29.6)$ & $16.3(9.6-28.8)$ & - \\
\hline Acetabulum width & $16.9(5.6-32.6)$ & $16.4(9.6-33.6)$ & - \\
\hline
\end{tabular}


(SANDLAND; GOATER, 2001) and in the behavior of infected fish. Such brain and visual changes expose infected fish to predators such as aquatic piscivorous birds (BULLARD; OVESTREET, 2008), definitive hosts of this parasite.

Species of Curimatella are detritivorous fish that consume algae, debris, and associated microorganisms. Acaronia nassa, C. espectabilis and S. acuticeps are omnivorous fish that feed on aquatic invertebrates, algae, insects, and fish. Crenichla marmorata is a carnivorous fish that feeds on aquatic invertebrates and fish (SANTOS et al. 2004; FROESE; PAULY, 2017). Biomphalaria straminea and Biomphalaria glabrata snails were identified to be intermediate hosts of $A$. compactum in a lake in the southeast of Brazil (PINTO; MELO, 2013). In the lake studied in the present study, the presence of snails of the genus Pomacea, possible intermediate hosts of Austrodiplostomum spp. in the environment, was observed. Austrodiplostomum spp. adults inhabit the digestive tract of piscivorous birds such as Phalacrocorax brasilianus (PINTO; MELO, 2013; MONTEIRO et al., 2016), which has a large presence in the area of the present study, together with Ardea alba, snails, and fish, are believed to maintain the biological cycle of $A$. compactum in the region of the Amazonian ecosystem investigated here.

In C. espectabilis, S. acuticeps, Curimatella sp., C. marmorata, and $A$. nassa, there were low levels of infections by the metacercariae of Austrodiplostomum spp. Similar results were reported for Hypostomus hermanni, Hypostomus iheringii and Hypostomus sp. with A. compactum infection in the eyes (ZICA et al., 2011). However, high levels of $A$. compactum infections have been reported for $P$. squamosissimus from Paraná River, in the São Paulo state (SANTOS et al., 2002) and Cataláo Lake, in the state of Amazonas (ALBUQUERQUE et al., 2017).

The measurements of Austrodiplostomum spp. from this study were similar to those described by ALBUQUERQUE et al. (2017) for P. squamosissimus from the western Amazon region. PINTO; MELO (2013) found that the morphometric measurements of $A$. compactum metacercariae obtained from experimentally infected Cyprinus carpio were similar to those from other fish. However, they were different from the measurements reported by YAMADA et al. (2008) for S. maculatus, $H$. regani, A. osteomystax, and $S$. borelli from the Paraná River Basin (Brasil).

\section{CONCLUSIONS}

Due to the low specificity of Austrodiplostomum spp., it has been found in several hosts of different watersheds. In this study, we extended the record of its geographic distribution to the eastern Amazon region, as well as added C. espectabilis, S. acuticeps, Curimatella sp., C. marmorata, and A. nassa as secondary hosts of Austrodiplostomum spp., increasing to 14 the number of hosts for this digenean in the Brazilian Amazon.

\section{ACKNOWLEDGEMENTS}

The authors would like to thank the Conselho Nacional de Desenvolvimento Científico e Tecnológico (National Council for Scientific and Technological Development) (CNPq) for the undergraduate scholarship (PIBIC) awarded to Márcio Jonathan Soares, and productivity grant awarded to the Dr. Marcos Tavares-Dias (\#303013/2015-0). The authors would like to thank Dr. Luciano Jensen Vaz for his contribution to the care of the animals in the Multi-laboratory for the Production of Aquatic Organisms and Dr. Eveleise Samira Martins Canto for her help with parasite extraction.

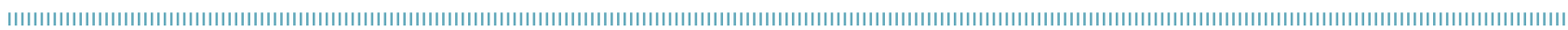
REFERENCES

ALBUQUERQUE, N.B.D.; MOREY, G.A.M.; MORAIS, A.M.; MALTA, J.C.O. Metacercariae of Austrodiplostomum compactum (Lutz, 1928) (Trematoda, Diplostomidae) infecting the eyes of Plagioscion squamosissimus (Heckel, 1840) (Perciformes, Scienidae) from Lake Catalão, Amazonas, Brazil. Acta Amazonica, v.47, n.2, p.141-146, 2017. https://doi.org/10.1590/1809-4392201602474

BULLARD, S.A.; OVESTREET, R.M. Digeneans as enemies of fishes. In: EIRAS, J.C.; SEGNER, H.; WAHLI, T.; KAPOOR, B.G. (Eds.). Fish diseases. Jersey: Sciences Publishers, 2008. p.817-976.

BUSH, A.O.; LAFFERTY, K.D.; LOTZ, J.M.; SHOSTAK, A.W. Parasitology meets ecology on its own terms: Margolis et al. revisited. Journal of Parasitology, v.83, n.4, p.575-583, 1997. https://doi.org/10.2307/ 3284227
CORRÊA, L.L.; SOUZA, G.T.; TAKEMOTO, R.M.; CECCARELLI, P.S.; ADRIANO, E.A. Behavioral changes caused by Austrodiplostomum spp. in Hoplias malabaricus from the São Francisco River, Brazil. Parasitology Research, v.113, n.2, p.499-503, 2014. https://doi.org/10.1007/s00436-013-3679-6

EIRAS, J.C.; TAKEMOTO, R.M.; PAVANELLI, G.C. Métodos de estudo e técnicas laboratoriais em parasitologia de peixes. 2. ed. Maringá: Eduem, 2006.

GIBSON, D.I.; JONES, A.; BRAY, R.A. Keys to the Trematoda. v.1. London: CAB International and the Natural History Museum, 2002.

FROESE, R.; PAULY, D. (Eds.). Fishbase, 2017. Available from: <https:// www.fishbase.in/summary/citation.php>. Access on: Feb. 132017. 
HECKMANN, R.A. Host records and tissue locations for Diplostomum mordax (metacercariae) inhabiting the cranial cavity of fishes from Lake Titicaca, Peru. Journal of Parasitology, v.78, n.3, p.541-543, 1992. https://doi.org/10.2307/3283665

JUNK, W.J. Current state of knowledge regarding South America wetlands and their future under global climate change. Aquatic Sciences, v.75, n.1, p.113-131, 2013. https://doi.org/10.1007/ s00027-012-0253-8

KOHN, A.; FERNANDES, B.M.; BAPTISTA-FARIAS, M.D.F.D. Metacercariae of Diplostomum (Austrodiplostomum) compactum (Trematoda, Diplostomidae) in the eyes of Plagioscion squamosissimus (Teleostei, Sciaenidae) from the reservoir of the Hydroeletric Power Station of Itaipu, Brazil. Memórias do Instituto Oswaldo Cruz, v.90, n.3, p.341-344, 1995. http:// dx.doi.org/10.1590/S0074-02761995000300005

LOCKE, A.S.; MCLAUGHLIN, J.D.; MARCOGLIESE, D.J. DNA barcodes show cryptic diversity and a potential physiological basis for host specificity among Diplostomoidea (Platyhelminthes: Digenea) parasitizing freshwater fishes in the St. Lawrence River, Canada. Molecular Ecology, v.19, n.13, p.2813-2827, 2010. https://doi. org/10.1111/j.1365-294X.2010.04713.x

MACHADO, P.M.; TAKEMOTO, R.M.; PAVANELLI, G.C. Diplostomum (Austrodiplostomum) compactum (Lutz, 1928) (Platyhelminthes, Digenea) metacercariae in fish from the floodplain of the upper Paraná River, Brazil. Parasitology Research, v.97, n.6, p.436-444, 2005. https://doi. org/10.1007/s00436-005-1483-7

MOURITSEN, K.N.; POULIN, R. Parasite-induced trophic facilitation exploited by a non-host predator: a manipulator's nightmare. International Journal for Parasitology, v.33, n.10, p.1043-1050, 2003. https://doi.org/10.1016/ S0020-7519(03)00178-4

MONTEIRO, C.M.; MARTINS, N.A.; ALBUQUERQUE, M.C.; SANTOS-CLAPP, M.D.S.; DUARTE, R.; SÃO SABAS, C.S.; BRASILSATO, M.C. Austrodiplostomum compactum Szidat \& Nani (Digenea: Diplostomidae) in final and second intermediate hosts from upper São Francisco river in the State of Minas Gerais, Brazil. Brazilian Journal of Veterinary Medicine, v.38, Suppl.3, p.146-150, 2016

NOVAES, J.L.C.; RAMOS, I.P.; CARVALHO, E.D.; SILVA, R.J. Metacercariae of Diplostomum compactum Lutz, 1928 (Trematoda, Diplostomidae) in the eyes of acara Geophagus brasiliensis Quoy \& Gaimard, 1824 (Teleostei, Cichlidae) from Barra Bonita Reservoir-São Paulo, Brazil. Arquivo Brasileiro de Medicina Veterinária e Zootecnia, v.58, n.6, p.1229-1231, 2006. http://dx.doi.org/10.1590/ s0102-09352006000600037
PINTO, H.A.; MELO, A.L. Biomphalaria straminea and Biomphalaria glabrata (Mollusca: Planorbidae) as new intermediate hosts of the fish eyefluke Austrodiplostomum compactum (Trematoda: Diplostomidae) in Brazil. Journal of Parasitology, v.99, n.4, p.729-733, 2013. https://doi.org/10.1645/12-13.1

SANDLAND, G.J.; GOATER, C.P. Parasite-induced variation in host morphology: brain-encysting trematodes in fathead minnows. Journal of Parasitology, v.87, n.2, p.267-272, 2001. https://doi. org/10.1645/0022-3395(2001)087[0267:PIVIHM]2.0.CO;2

SANTOS, R.D.S.; PIMENTA, F.D.A.; MARTINS, M.L.; TAKAHASHI, H.K.; MARENGONI, N.G. Metacercárias de Diplostomum (Austrodiplostomum) compactum Lutz, 1928 (Digenea, Diplostomidae) em peixes do Rio Paraná, Brasil. Prevalência, sazonalidade e intensidade de infecção. Acta Scientiarum Biological and Health Sciences, v.24, n.2, p.475-480, 2002. http://dx.doi.org/10.4025/actascibiolsci.v24i0.2350

SANTOS, G.M.; MÉRONA, B.; JURAS, A.A.; JÉGU, M. Peixes do baixo Rio Tocantins: 20 anos depois da Usina Hidrelética Tucuruí. Brasília: Eletronorte, 2004.

SIEGMUND, I.; FRANJOLA, R.; TORRES, P. Diplostomatid metacercariae in the brain of silversides from Lake Riñihue, Chile. Journal of Wildlife Diseases, v.33, n.2, p.362-364, 1997. https://doi.org/10.7589/0090-3558-33.2.362

VITAL, J.F.; MURRIETA-MOREY, G.A.; PEREIRA, N.B.; MALTA, J.C.O. Metacercárias de Austrodiplostomum compactum (Lutz, 1928) em peixes de lagos de várzea da Amazônia brasileira. Folia Amazónica, v.25, n.2, p.153-158, 2016. https://doi. org/10.24841/fa.v25i2.399

YAMADA, F.H.; MOREIRA, L.D.A.; CESCHINI, T.L.; TAKEMOTO, R.M.; PAVANELLI, G.C. Novas ocorrências de metacercária de Austrodiplostomum compactum (Lutz, 1928) (Platyhelminthes: Digenea) parasito de olhos de peixes da bacia do rio Paraná. Revista Brasileira de Parasitologia Veterinária, v. 17, n.3, p.163-166, 2008. http://dx.doi.org/10.1590/S1984-29612008000300010

ZICA, E.O.P.; SANTOS, K.R.; RAMOS, I.P.; ZANATTA, A.S.; CARVALHO, E.D.; SILVA, R.J. First case of an infection of the metacercariae of Austrodiplostomum compactum (Lutz, 1928) (Digenea, Diplostomidae) in Hypostomus regani (Ihering, 1905) (Siluriformes: Loricariidae). Pan-american Journal of Aquatic Sciences, v.4, n. 1, p.35-38, 2009.

ZICA, E.O.P.; BRANDÃO, H.; ZAWADZKI, C.H.; NOBILE, A.B.; CARVALHO, E.D.; SILVA, R.J. The occurrence of Austrodiplostomum compactum (Lutz, 1928) (Digenea: Diplostomidae) metacercariae in the eyes of loricariid fish (Siluriformes: Osteichthyes: Loricariidae) from Brazil. Journal of Helminthology, v.85, n. 1, p.73-79, 2011. https://doi.org/10.1017/SO022149X10000271 